\title{
Classroom Democracy and Learning Outcomes in Primary Schools in Francophone Africa
}

\author{
Aloysius Mom Njong
}

Abstract
Inspired by the UN Charter on the Rights of the Child, educational policy makers in Africa are requesting
schools to implement democratic practices in the classroom. This study attempts to shed light on the effects
of classroom democratic practices on cognitive and non-cognitive learning outcomes using cross-sectional
data about student performance and indicators of classroom democracy from Francophone African countries.
To simultaneously account for the cause and effect of democratic practices on learning achievements and
the nested nature of the data, use is made of the error components-two stage least squares estimator. The
results confirm the endogenous nature of learning outcomes and indicate that teachers and parents are
the most important stakeholders in the process of having children internalize democracy in the classroom.
It is recommended that teachers develop skills to assign and supervise pupils' work in small groups in the
classroom. Education stakeholders should take measures to preserve and promote indigenous cultural values
because they facilitate learning achievements.
Keywords: Classroom democracy, Educational outcomes

\section{Introduction}

Francophone Africans are familiar with classrooms where the teacher is the principal actor with all attention focused on them. Francophone Africa includes countries where French is the official language even if not all residents speak French, a result of the influence of historical French colonization. Like in many other countries, teachers transmit textbook knowledge to pupils who are encouraged to memorise the course material, perhaps only to reproduce it on demand, usually to pass an examination. In such traditional and authoritarian schools, textbooks and teachers are the main sources of knowledge, and children are hardly encouraged to participate. There is a growing awareness that such teacher-centred and text-book centred instructional approaches produce future passive citizens who fall short of critical thinking, decision-making and socialisation skills (Barron \& Darling-Hammond, 2008; Nagaraju, Madhavaiah, \& Peter, 2013). Given this awareness and inspired by the UN Charter on the Rights of the Child, educational policy makers in Africa

Full listing of authors and contacts can be found at the end of this article. are requesting the enhancement of democracy in the classroom which is more likely to promote children's social, moral and academic development (UN General Assembly, 1989). Despite this policy directive, very little attention has been paid to the practice of democratic principles in the classroom and the delivery of education in a transformative manner. Perhaps research in this area has been hampered by the lack of readily available data, and difficulties in quantifying social education variables (Borghans, Duckworth, Heckman, $\&$ Ter Weel, 2008). The traditional education production function has centred on conventional schooling input-output variables perhaps because these are more easily measurable. Non-conventional inputs such as democratic practices have been neglected.

As part of classroom democratic practices, I agree with Serpell \& Marfo (2014), Bodrova \& Leong (2007), and Mucherah \& Mbogori (2019) who argue that learning outcomes are influenced by the cultural values and norms of the local setting where children go to school. African countries have cultural values which are specific and diverse and often different from those in developed countries. Yet few attempts are made to explicitly

Published by the Global Insitutute of Transformative Education (http://wwww.gite.education) (c) Njong, A. M.,. 2020. Open Access This journal is distributed under the terms of the Creative Commons Attribution NonCommercial NonDerivative 4.0 International License (http://creativecommons.org/licenses/by-nc-nd/4.0/), which permits unrestricted use, distribution, and reproduction without revision in any non-commercial medium, provided you give appropriate credit to the original author(s) and the source, provide a link to the Creative Commons license, 
factor in African cultural values in the education production processes. Thus, in this study an attempt is made to consider some aspect of African cultural identity as a special dimension of classroom democracy in the modelling, and to show how it contributes to the motivation of children's educational achievements in Francophone Africa. In addition to issues of data availability, the focus of the study on Francophone African countries is to capture the hangovers of French colonialism on the school curriculum of these countries. There may be some aspects of French colonialism and post-colonialism that interact with other factors to shape schooling realities in postcolonial Francophone African countries.

As concerns learning outcomes, focus in the literature has been on literacy and numeracy test scores (Glewwe \& Jacoby, 1994; Glewwe, 2002; Glewwe \& Kremer, 2006; Wamalwa \& Burns, 2018). Non-cognitive outcomes have not been given the attention they deserve, perhaps because they are difficult to measure. The classroom should not only aim to produce individuals who can read and write, but must go beyond to prepare active, sociable, culturally viable and well-behaved citizens of the country.

Another motivation for this study is at the methodological level. From the foregoing, it is apparent that schooling produces several learning outcomes, such as formal cognitive skills and behavioural skills. These educational outcomes are jointly determined in the learning process and any single equation modelling may not capture the entire picture of interrelationships in the educational process. Therefore, I attempt to take into account the simultaneity and interdependence between learning outcomes and inputs, leading to a more realistic formulation of the schooling production function. Another important methodological issue is related to the nested nature of the data. Ignoring clustering in analysing hierarchically structured data will underestimate standard errors due to the decrease in the effective sample size for explanatory variables defined at the cluster level (Baltagi, 2011).

It is against this backdrop that this study seeks to establish the causal relationships between democracy in the classroom and learning outcomes in primary schools in Francophone African countries. Specifically, the study attempts to:

i. analyse democratic practices in schools as an approach to classroom management in Francophone African countries. ii. determine the effects of classroom democracy on learning outcomes in primary schools across Francophone African countries.

The study is organised as follows: Section 1 explains the context and motivation of the study. Section 2 presents the conceptual framework wherein the concepts of classroom democracy and learning achievements are defined and operationalized. Section 3 dwells on the methodology which describes the data used, model specification and estimation strategies. Section 4 is reserved for results and discussions. Section 5 concludes the study with a summary of the key findings, together with educational policy implications.

\section{Conceptual Framework}

In this section, I define the concepts of classroom democracy and learning outputs in the context of this study so as to establish the causal relations between them.

\section{Classroom Democracy}

A modern pedagogical approach to classroom democracy focuses on the promotion of self-learning (Fearnley-Sander, Moss, \& Harbon, 2001). This means that pupils are actively engaged with their own learning. To be more explicit, I consider classroom democracy as a set of classroom practices that put the children at the centre of the instructional process. This requires that each pupil is accepted as a unique personality and shown respect. It also requires that pupils' opinions be considered in education decision-making. As members of the society make decisions in a democracy, so the pupils who are actual elements in the democratic classroom should actively participate in decision making. For example, the curriculum to be taught and rules to be obeyed at school and in the classroom should be determined together with pupils. Democracy comes along with freedom of thinking and expression. Consequently, pupils should be given the opportunity to express what they feel and think.

The democratic classroom as a way of life is reinforced by the UN Convention on the Rights of the Child (UN General Assembly, 1989) which proposes relationship changes between adults and young children. Both parents and teachers are expected to be agents of change in the learning process of the child. In building a democratic classroom culture, the role of the teacher has to change from an authoritative personality to a facilitator. The teacher is no longer that person dictating a lesson as pupils copy and assimilate, but is expected 
to help pupils to cultivate the habit of accessing information by themselves and learning it (Maftoon \& Shakouri, 2012). The teacher is expected to guide the pupils in their learning process, and not force them to learn. The parent is expected to promote processes designed to enable and empower children to learn conveniently. Such processes would involve providing children with basic needs such as adequate nutrition, health, and protection against abuse and violence.

Another dimension of classroom democracy is enshrined in the concept of discipline in schools. It is well recognized that if discipline is not taken into consideration, the classroom/school environment will be unsafe and may disrupt the learning process as well as the academic achievement of the children (Mothata \& Squelch, 1997; Levin \& Nalon, 1991). Teachers and school administrators have a major role to play through guidance and counseling of children in order to instill in them a sense of responsibility and curb incidences of disruptive behaviour in schools. Every school has a code of conduct which every child is supposed to respect. When the rules are broken, it is expected that disciplinary measures be applied according to the educational regulations in force. Therefore, it is important to factor in child discipline as a transformative educational input that will lead to a healthy classroom environment in a democratic manner.

Another dimension of classroom democracy may be borrowed from social cultural theory which holds that culture and social interactions are essential factors in children's acquisition of knowledge (Okonji, 1971; Bodrova \& Leong, 2007; Marfo \& Biersteker, 2011; Marfo, Pence, Levine, \& Levine, 2011; Mucherah \& Mbogori, 2019). The African child grows up in a local context where the mother tongue is spoken, traditional music is listened and danced to with formidable dexterity, domestic chores are often distributed among family members, and telling of folk stories are common practices. Furthermore, the extended family system which includes, in addition to nuclear family; uncles, aunties, cousins and grandparents is order of the day (Degbey, 2012). Democracy as a way of living and everyday experiences should not be indifferent to these local contextual factors in which African children are growing. Therefore, African socio-cultural values need to be extended to the classroom setting in order to properly motivate children in the learning process in the context.

\section{Learning Outcomes}

Learning outcomes are multidimensional and complex. However, to facilitate understanding I divide learning outputs into cognitive and non-cognitive components.

According to Anderson et al (2001) the cognitive domain involves the acquisition of knowledge and the development of intellectual skills from the educational process. This way of learning encourages pupils to use their brains more effectively, and enables them to think and remember easily. This does not mean that memorisation or repetition is encouraged, it simply ensures that the concepts learnt in class are understood. Outcomes from the cognitive learning process usually involve academic achievement tests in reading, language and mathematics.

The non-cognitive component is made up of self-esteem and sociability outcomes. According to Emler (2001), Olsen, Breckler, \& Wiggens (2008) and Harter (2012), self-esteem is considered a child's evaluation of self-worth and acceptance in the classroom. It is a judgment of the self. Research results indicate that there is a correlation between self-esteem and children's development (Papadopoulos, Metsiou, \& Agaliotis, 2011). For example, children with high self-esteem show greater motivation and take initiative. They are more prone to express sociable behavior and show more feelings of happiness (Baumeister, Campbell, Krueger, \& Vohs, 2003). On the other hand, children who have low selfworth tend to treat themselves badly and are more likely to invite bad treatment from their peers (Saigal, Lambert, Russ, \& Hoult, 2002). The consequences of low self-worth amongst pupils would include unhappiness, symptoms of depression, and difficulties in forming and sustaining friendly relationships with their peers (Emler, 2001). The social outcome of the education process revolves around the social learning theory (Bandura, 1977). The theory posits that people can acquire new behaviours by observing and imitating the behavioural patterns of other people. The theory further posits that learning would also occur through practices of rewards and punishments. In this way, a behaviour that is often rewarded would persist, while the one that is constantly punished would most likely not be imitated. The classroom is a social setting, and pupils through their interactions with peers and teachers would pick up new patterns of behaviour that are likely to uphold the spirit of team work, cooperation and love for one another. 


\section{Methodology}

In order to understand the causal relationship between democratic classroom practices and learning achievement, secondary cross-sectional data collected by reviewing PASEC surveys were used. The PASEC survey methodology was a stratified samplying design where schools were first randomly selected, and grade 6 kids were subsequently randomly interviewed from each school. Given the stratified nature of the data collection process, multilevel analytical framework is adopted to better unravel the inter-relationships, but before addressing this, a discussion of the data generation procedure is necessary.

\section{Data}

Since 1960 The Conference of Ministers of Education of Francophone countries, better known in French acronym as CONFEMEN ${ }^{1}$, has been making enormous attempts to promote the delivery of educational services and professional training (PASEC, 1998). To facilitate this, it pilots a survey called 'Programme d'Analyse des Systèmes Éducatifs de la CONFEMEN' (PASEC) to collect data that are used to assess the efficiency of the educational systems of its member countries. The data I use in this study come from the PASEC survey conducted across 10 Francophone African countries in 2014 (PASEC 2017). As part of the PASEC survey design information was collected from pupils in grade 6 who are at the end of the primary school curriculum. The information collected from these pupils included reading and numeracy test scores and the pupils' characteristics. Information was also collected from the children's parents, teachers and head teachers of the various schools relating to knowledge, welfare, pedagogic resources and governance issues. The 2014 PASEC design surveyed 31213 pupils in grade 6 nested in 671 schools across 10 countries ${ }^{2}$. The unit of analysis is the pupil.

\section{Measurement of Constructs}

Apart from the cognitive skills' construct, the rest of the constructs in the survey data are captured using several items. I subjected the items in each construct to an internal consistency test and retained for analysis only those items with positive inter-items correlations and/or that loaded high on the construct in question. The Cronbach's alpha test was used for 3-4 points Likert scales items, while the Guttman's split lambda coefficient was used for yes/no responses. Retaining

${ }^{1}$ CONFEMEN is Conférence des Ministres de l'Éducation des États et Gouvernements de la Francophonie.

${ }^{2}$ The ten countries are: Benin; Burkina Faso; Burundi; Cameroon; Congo; Cote D'Ivoire; Niger; Senegal; Tchad; and Togo only the items that pass the reliability or internal consistency test in analysis improves measurment of the latent constructs and facilitate the convergence of estimations (Wooldridge, 2009). Based on the retained items in each construct I built composite indicators using multiple correspondence analyses (Njong \& Ningaye, 2008). In this sub-section I analyse the measured latent variables/constructs of interest in this study.

\section{Indicators of classroom democracy}

The main explanatory variable in this study is classroom democracy. Drawing from the conceptualisation of classroom democracy in section 2, I build and analyse four composite indicators of classroom democracy. The first is the indicator of group work. This composite indicator is captured based on primary items shown on Table S1 (see Appendix). Table S1 indicates that about $38 \%$ of the teachers organised the children to work in small groups. About $67 \%$ of the teachers reported they lack the techniques to make pupils work as teams, while $56.3 \%$ of them complained that the classroom is inappropriate to organise children in smaller groups. The second construct of classroom democracy is an indicator of children's rights. The primary items of children's basic rights retained are displayed on Table

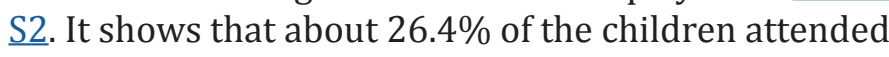
nursery school, while $64 \%$ of them slept under mosquito nets. As concerns health challenges, $17.7 \%$ of the children reported having hearing difficulties, and 23\% had sight problems. Children nutrition seems to be a serious problem because about $57.5 \%$ of the children reported always feeling hungry in class. The third construct of classroom democracy is an indicator of child discipline. Child discipline was surveyed by getting responses to the statements captured on Table S3. It is observed on Table S3 that about 38\% of the teachers punished or shouted at children in class. The method of punishment ranged from asking the pupils to copy exercises (32\%), and /or do manual labour (49\%). Note that about $5.5 \%$ of the teachers did administer corporal punishment although it is prohibited by law in these countries. The fourth construct of classroom democracy is an indicator of cultural identity. The statements that captured cultural identity, and based on which the cultural identity indicator is built, are displayed on Table

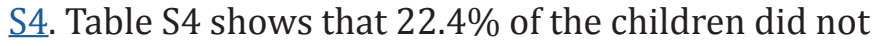
speak their mother tongue at home, while $69 \%$ of them did so occasionally. Only about $18.5 \%$ of the teachers used the native language spoken by the children of that

${ }^{3}$ In the case of items with mixed scales, I used the Cronbach's alpha test. 
locality. Above $70 \%$ of the teachers did not allow children talk or sing songs in their mother tongue in class. Table S4 also indicates that 77-84\% of the schools did not have textbooks in the language of the majority of the children.

\section{Dependent variables}

The dependent variables are learning outcomes which are cognitive and non-cognitive and are considered endogenous, because they are determined within the system ${ }^{4}$. The cognitive outcomes are standard scores in reading skills and mathematics skills. This is a simple scale of test scores that are continuous from grade 2 through grade 6 . The standard scores reported for each of the grade levels ranges from 100 to 400. I compute the mean value of the test scores across the grades for reading and math. These scores indicate that the higher the score, the higher the academic achievement of the child.

The non-cognitive outcomes are self-esteem and sociability. The items used to measure non-cognitive skills include measures of friendliness, happiness, self-worth, cooperation with one another, and feeling of security. Each child was asked to respond to the descriptive statements measuring self-esteem and sociability captured on a 4-point Likert scale as follows: 1) strongly agree, 2) agree, 3) disagree, and 4) strongly disagree. The number of items in the survey that are related to self-esteem and sociability are ten and six respectively. Based on Cronbach's alpha analysis, I selected seven and four items that loaded high on self-esteem and sociability respectively (see Tables S5 and S6). Table $\underline{\mathrm{S} 5}$ shows children's responses to self-esteem items. It shows that over $83 \%$ of the children reported performing well in class. Approximately $81 \%$ of the children reported hard work to account for their good achievement, while $74 \%$ of them attributed the good scores to the fact that class lessons are easy. Children reported having low scores for various reasons, for example about $47 \%$ of them don't study enough, and $36 \%$ of them consider they are not intelligent enough, while $25 \%$ said the teacher insults them. Table S6 shows children's responses to sociability items, where over $80 \%$ of them agreed having many friends in school. About $87 \%$ of the children were happy being in school because their peers like them.

It is important to note that the learning outcome/ endogenous variables are measured in different units. The non-cognitive skills are measured using Likert scales in the survey dataset while the cognitive skills

\footnotetext{
${ }^{4}$ This is explained in greater detail in Methodology section.
}

are mean test scores. Thus, in order to facilitate interpretation of changes on learning outcomes I transformed them into a common unit of measurement using standard z-scores.

\section{Model Specification}

To determine the effects of classroom democracy on learning outcomes an econometric model is specified. Since the schooling inputs jointly produce the educational outcomes, a simultaneous equation modelling approach is deemed appropriate for this study. Simultaneous-equation models specify relationships in a system of two or more equations where the dependent variables display an interdependent relationship (Wooldridge, 2009; Greene, 2011; Baltagi, 2011). In a non-recursive model of this nature, the focus is on the relationship among the jointly determined dependent variables in the systems, which are considered endogenous. I argue that these endogenous variables are considered cause and effect in the schooling production process. There is simultaneity or reciprocal causation among the dependent variables. The modelling suggests that certain outcomes could be affected directly by other outcomes of the educational process. What this means is that all the dependent variables are explicitly taken to be endogenous to the system (Baltagi, 2011). That is, the endogenous explanatory variables are dependent variables from other equations in the system. Given the above, I can specify the following non-recursive system of simultaneous equations:

MTS $_{\mathrm{ijc}}=\alpha_{0}+\alpha_{1} \mathrm{ICD}_{\mathrm{ijc}}+\alpha_{2} \mathrm{RTS}_{\mathrm{ijc}}+\alpha_{3} \mathrm{ISO}_{\mathrm{ijc}}+\alpha_{4} \mathrm{ISE}_{\mathrm{ijc}} \gamma \mathrm{X}_{\mathrm{ijc}}+\varepsilon_{1, \mathrm{jic}}$ $\operatorname{RTS}_{\mathrm{ijc}}=\beta_{0}+\beta_{1} \mathrm{ICD}_{\mathrm{ijc}}+\beta_{2} \mathrm{MTS}_{\mathrm{ijc}}+\beta_{3} \mathrm{ISO}_{\mathrm{ijc}}+\beta_{4} \mathrm{ISE}_{\mathrm{ijc}}+\theta \mathrm{W}_{\mathrm{ijc}}+\varepsilon_{2, \mathrm{ijc}}$

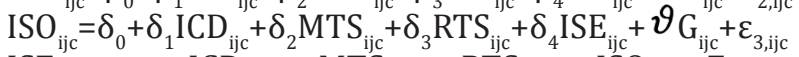
$\mathrm{ISE}_{\mathrm{ijc}}=\omega_{0}+\omega_{1} \mathrm{ICD}_{\mathrm{ijc}}+\omega_{2} \mathrm{MTS}_{\mathrm{ijc}}+\omega_{3} \mathrm{RTS}_{\mathrm{ijc}}+\omega_{4} \mathrm{ISO}_{\mathrm{ijc}}+\pi Z_{\mathrm{ijc}}+\varepsilon_{4, \mathrm{ijc}}$ where:

$$
\begin{aligned}
& \text { MTS }=\text { Math test scores } \\
& \text { RTS = Reading test scores } \\
& \text { ISO = Indicator of Sociability } \\
& \text { ISE }=\text { Indicator of Self-esteem } \\
& \text { ICD }=\text { Indicators of classroom democracy } \\
& X, W, G, Z=\text { vector of control (exogenous) variables } \\
& \alpha, \beta, \gamma, \delta, \theta, \pi, \vartheta, \omega \text { are structural parameters to be estimated } \\
& \varepsilon_{1}, \cdots, \varepsilon_{4} \text { are disturbance or error terms } \\
& i, j, c \text { represent the } i^{\text {th }} \text { pupil, the } j^{\text {th }} \text { school, } \\
& \text { and } c^{\text {th }} \text { country respectively }
\end{aligned}
$$

The explanatory endogenous variables are correlated with the error terms in the system of equations. All other explanatory variables are considered exogenous to the system and uncorrelated with the error terms. The exogenous variables are considered as instruments for the endogenous variables. 


\section{Model Estimation}

To estimate a system of simultaneous equations, instrumental variable methods for joint estimation are often proposed. To account for the nested structure of the data due to intra-school correlations that may arise because responses from children in the same school are likely to be similar while those from children in other schools are different, the solution in single equation model is to cluster the errors at the level of the school (Fielding, 2010; Wamalwa \& Burns, 2018). To achieve this within a simultaneous equation framework, Baltagi \& Chang (2000) and Hsiao (2003) proposed an error components-two stage least squares (ec2sls) estimator to account for the random error component of the system of equations. The ec2sls estimator is implemented on an equation by equation estimation basis (Baltagi, $2008)^{5}$ to avoid having inconsistent equation estimates for all the equations in the event where any of the equations is mis-specified.

\section{Pair-wise Correlation Results}

Table 1 shows the weighted ${ }^{6}$ pair-wise correlations between the classroom democratic indicators and learning outcomes as defined in this study.

\$Table 1. Correlation matrix of key variables

\begin{tabular}{lllllllll}
\hline & MTS & RTS & ISE & ISO & IGW & ICR & ICD & ICI \\
\hline MTS & 1 & & & & & & & \\
RTS & .845 & 1 & & & & & & \\
ISE & .154 & .201 & 1 & & & & & \\
ISO & .092 & .139 & .590 & 1 & & & & \\
IGW & .094 & .058 & .002 & .015 & 1 & & & \\
ICR & .058 & .067 & .006 & .004 & .030 & 1 & & \\
ICD & .059 & .027 & .028 & .036 & .168 & -.008 & 1 & \\
ICI & .035 & .043 & .001 & .017 & -.021 & -.024 & -.002 & 1 \\
\hline
\end{tabular}

Source: Constructed using 2014 PASEC grade 6 data

Note: MTS=math test score; RTS=reading test score; ISE=indicator of self-esteem; ISO=indicator of sociability; ICR=indicator of child's rights; ICD=indicator of child discipline; ICI=indicator of cultural identity.

Table 1 shows some preliminary partial inter-relationships among learning outcomes and classroom democratic indicators. First observation on Table 1 is that there is a high positive correlation between the cognitive educational outputs. The correlation coefficient between math skills and reading test scores is 0.845 indicating that pupils who read well report high performance in mathematics as well. Second interesting observation is that correlation between non-cognitive outcomes is moderate and positive. For instance, the

\footnotetext{
${ }^{5}$ Baltagi's (2008) ec2sls can be obtained by specifying the ec2sls option, after xtivreg in Stata.
}

correlation coefficient between self-esteem and sociability is 0.59 , indicating that that children who have high self-esteem are much likely to be sociable. Third observation of interest is that the correlation between the cognitive and the non-cognitive indicators are positive but much lower. For example, correlation coefficient between self-esteem and reading is 0.201 , while it is 0.155 with math. The correlations among the indicators of classroom democracy are very low.

\section{Estimation Results}

In this section the regression results of classroom democratic practices on learning outcomes are presented. For convenience, the results for cognitive skills are presented first. Table 2 (see next page) displays the estimation results for cognitive skills.

The results on Table 2 show high positive and significant correlations between both test scores at the $1 \%$ level. This result suggests that a child who does well in reading generally will also achieve well in math, and vice versa. The other two endogenous variables; self-esteem and sociability also show significant positive, but much lower correlations with math and reading skills.

As concerns the indicators of classroom democracy, the correlations are positive and insignificant, except for child discipline. The results are interpreted in terms of standard deviations (SDs). The indicator of group work correlates positively with cognitive skills. This means that a one unit increase in the indicator of group work improves math and reading scores by .073 SDs and .065 SDs respectively, but the effects are insignificant. The results indicate that when children's rights increase by one unit, math and reading test scores rise insignificantly by .068 and .052 SDs respectively. The indicator of child discipline associates positively and significantly with cognitive skills (.052 SDs for math and .083 SDs for reading). The indicator of cultural identity indicates that when it increases by one unit, math scores improve by .061 SDs; while reading scores increase by .071 SDs.

Of the control variables, the following are positive and significant at least at the 5\% level: household size, teacher experience, teacher's training, community involvement in school management, classroom pedagogic resources, and school infrastructure. The models predict that higher test scores are associated with students who are male, though this finding is insignificant.

\footnotetext{
${ }^{6}$ The PASEC survey provides several types of sampling weights, notably child, teacher, or school weights depending on the level of analysis. Since unit of analysis in this study is the child, I use child sampling weights.
}

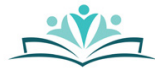


Teacher absenteeism has negative significant effects on academic achievements.

The diagnostics statistics on Table 2 show that the variables specified in the models accounted for approximately $27.4 \%$ of the total variance of the math scores, and $37.1 \%$ of reading test scores, respectively. The between variations

Table 2. Estimation results for cognitive skills

\begin{tabular}{|c|c|c|}
\hline Variable & $\begin{array}{l}\text { Math test } \\
\text { Score (1) }\end{array}$ & $\begin{array}{l}\text { Reading } \\
\text { test } \\
\text { Score (2) }\end{array}$ \\
\hline \multicolumn{3}{|l|}{ Dependent/Endogenous variables } \\
\hline Math test score & - & $\begin{array}{l}.689^{* * *} \\
(.115)\end{array}$ \\
\hline Reading test score & $\begin{array}{l}.772^{* * *} \\
(.028)\end{array}$ & - \\
\hline Self-esteem & $\begin{array}{l}.209 * * * * \\
(.007)\end{array}$ & $\begin{array}{l}.371^{* * * *} \\
(.068)\end{array}$ \\
\hline Sociability & $\begin{array}{l}.083^{* * * *} \\
(.005)\end{array}$ & $\begin{array}{l}.119^{* * *} \\
(.007)\end{array}$ \\
\hline \multicolumn{3}{|l|}{ Indicators of classroom democracy } \\
\hline Indicator of group work & $\begin{array}{l}.073 \\
(.065)\end{array}$ & $\begin{array}{c}.065 \\
(.055)\end{array}$ \\
\hline Indicator of children's rights & $\begin{array}{l}.068 \\
(.059)\end{array}$ & $\begin{array}{l}.052 \\
(.048)\end{array}$ \\
\hline Indicator of child discipline & $\begin{array}{l}.052^{* * * *} \\
(.012)\end{array}$ & $\begin{array}{l}.083^{* * * *} \\
(.005)\end{array}$ \\
\hline Indicator of cultural identity & $\begin{array}{l}.061 \\
(.079)\end{array}$ & $\begin{array}{l}.071 \\
(.056)\end{array}$ \\
\hline \multicolumn{3}{|l|}{ Control /exogenous covariates } \\
\hline Gender (Female=ref) & $\begin{array}{l}.005 \\
(.009)\end{array}$ & $\begin{array}{l}.006 \\
(.003)\end{array}$ \\
\hline Family size & $\begin{array}{l}.002^{* *} \\
(.001)\end{array}$ & $\begin{array}{l}019^{* * *} \\
(.009)\end{array}$ \\
\hline Socio-economic status & $\begin{array}{l}.020^{* *} \\
(.009)\end{array}$ & $\begin{array}{l}002 * \\
(.001)\end{array}$ \\
\hline \multicolumn{3}{|l|}{ Teacher characteristics } \\
\hline Experience & $\begin{array}{l}.014^{*} \\
(.007)\end{array}$ & $\begin{array}{c}.009 \\
(.007)\end{array}$ \\
\hline Experience - squared & $\begin{array}{l}.016^{* * *} \\
(.001)\end{array}$ & $\begin{array}{l}.022^{*} \\
(.010)\end{array}$ \\
\hline Teacher training (years) & $\begin{array}{l}.002 \\
(.004)\end{array}$ & $\begin{array}{c}.005 \\
(.020)\end{array}$ \\
\hline Teacher absenteeism & $\begin{array}{c}-.005^{* * * * *} \\
(.001)\end{array}$ & $\begin{array}{l}-.009^{* *} \\
(.002)\end{array}$ \\
\hline \multicolumn{3}{|l|}{ School/Classroom characteristics } \\
\hline Community involvement & $\begin{array}{l}.004^{* * *} \\
(.001)\end{array}$ & $\begin{array}{l}.019^{* *} \\
(.008)\end{array}$ \\
\hline Classroom pedagogic resources & $\begin{array}{l}.039^{* * *} \\
(.013)\end{array}$ & $\begin{array}{l}.002^{*} \\
(.001)\end{array}$ \\
\hline School infrastructure & $\begin{array}{l}.028 \\
(.038)\end{array}$ & $\begin{array}{c}.002 \\
(.004)\end{array}$ \\
\hline Constant & $\begin{array}{l}.102^{*} \\
(.060)\end{array}$ & $\begin{array}{l}.434^{* *} \\
(.152)\end{array}$ \\
\hline Diagnostic test statistics & & \\
\hline $\begin{array}{l}\text { R-sq within } \\
\text { R-sq between }\end{array}$ & $\begin{array}{l}.221 \\
.568\end{array}$ & $\begin{array}{l}.327 \\
.593\end{array}$ \\
\hline R-sq overall & .274 & .371 \\
\hline F-stat & $\begin{array}{l}253.04 \\
p=.000\end{array}$ & $\begin{array}{l}259.21 \\
p=.000\end{array}$ \\
\hline $\begin{array}{l}\text { Number of groups (schools) } \\
\text { Number of observations }\end{array}$ & $\begin{array}{l}665 \\
28,543\end{array}$ & $\begin{array}{l}665 \\
28,714\end{array}$ \\
\hline
\end{tabular}

Source: Constructed using 2014 PASEC grade 6 data

Notes: ${ }^{*} p<.1, * " p<.05,{ }^{* * *} p<.001$

Robust standard errors are reported in parentheses.
(R-sq=56.8\% for math; $59.3 \%$ for reading) accounted more than the within variations ( $\mathrm{R}-\mathrm{sq}=22.1 \%$ for math; $32.7 \%$ for reading) in explaining the overall variances of the models, respectively. The F-values are statistically significant at the $1 \%$ level. This indicates that the regression models fit the data structure. In other words, the estimates of each model taken together are significant. Table 3 displays the estimation results for non-cognitive skills.

The results on Table 3 show a moderately positive and significant association between self-esteem and sociability. Specifically, a unit increase in self-esteem improves sociability by .051 SDs. This suggests that a child's feeling of self-esteem is affected by their interest in other children and the reactions they receive in return. The other two endogenous variables; math and reading show much lower positive and significant correlations with self-esteem and sociability skills.

As regards the indicators of classroom democracy, the associations are positive and insignificant, except for child discipline. The indicator of group work is shown to associate positively and insignificantly with self-esteem (0.011 SDs) and sociability (.057 SDs). As concerns the indicator of children's rights, Table 3 shows that a one unit increase in children's rights improves self-esteem and sociability insignificantly by .013 and .035 SDs respectively. The indicator of child discipline associates positively and significantly with non-cognitive skills (.022 SDs for self-esteem and .024 SDs for sociability). Table 3 also indicates that when indicator of cultural identity increases by one unit, self-esteem improves by .026 SDs; while sociability ameliorates by .006 SDs, though these improvements are insignificant.

As concerns the other exogenous correlates, the following relate positively and significantly with the non-cognitive outcomes: household size, socio-economic status, teacher experience-squared, community involvement in school management, and classroom pedagogic resources. The models predict school infrastructure, teacher's professional training, and experience associate positively though insignificantly with non-cognitive skill. As expected, teacher absenteeism has negative, though insignificant effect on non-cognitive achievements. Precisely, a unit increase in teacher absenteeism causes self-esteem to change by -.004 SDs, while sociability changes by -.022 SDs.

The diagnostics tests on Table 3 show that the variables specified in the models accounted for approximately $29.1 \%$ of the total variance for self-esteem, and 
Table 3. Estimation results for non-cognitive skills

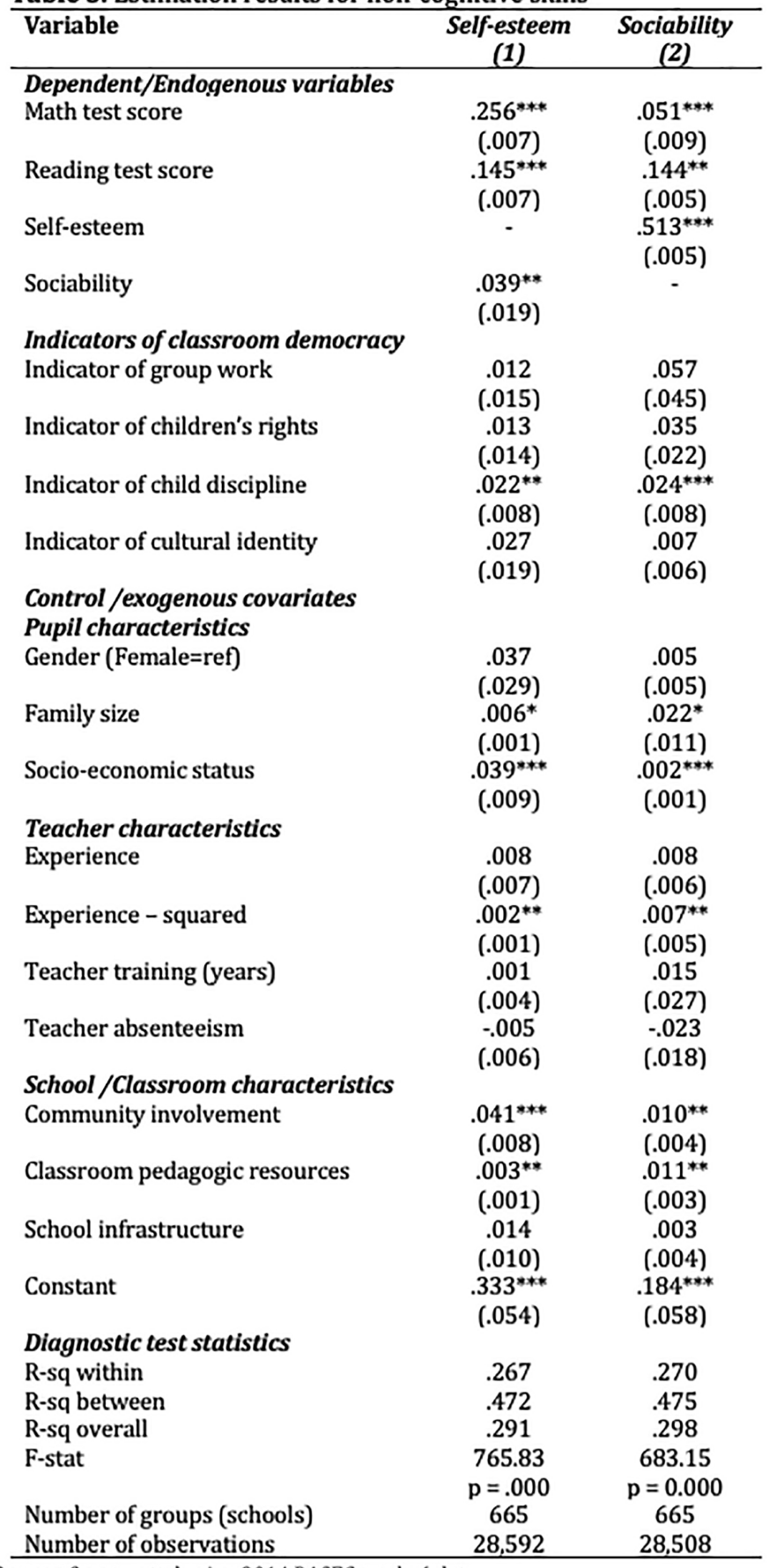

Source: Constructed using 2014 PASEC grade 6 data

Notes: * $p<.1, * * p<.05, * * * p<.001$

Robust standard errors are reported in parentheses.

$29.9 \%$ of sociability, respectively. The between variations (R-sq $=47.3 \%$ for self-esteem; $47.5 \%$ for sociability) accounted more than the within variations (R-sq=26.7\% for self-esteem; $27.0 \%$ for sociability) in explaining the overall variances of the models, respectively. The F-statistics indicate that the regression models fit the data structure.

\section{Discussion}

The estimation results of this study show positive and significant inter-relationships between the learning outcomes of math, reading, self-esteem and sociability. In an attempt to explain these positive correlations, I draw from the theory of self-determination (Deci, Vallerand, Pelletier \& Ryan, 1991). According to this theory intrinsically motivated individuals will engage in actions or behaviours because they enjoy doing them. In this case the individual has an internal motivation and feels fully engaged to undertake the action. This contrasts with externally motivated behaviours that individuals may initiate because they expect a reward or want to avoid a punishment. Thus, it is expected that pupils who are intrinsically motivated (have high self-esteem and sociability) exhibit higher conceptual understanding (Deci, Vallerand, Pelletier \& Ryan, 1991). Such children are more confident in their capacities and therefore have greater interest for learning. These results corroborate the study by Noftle \& Robins (2007) who found positive association between the personality dimensions of students and their math GPA and verbal test scores. Chamorro-Premuzic \& Furnham (2003) have also reported positive significant correlation between personality traits and student academic performance.

The estimation results of this study portray positive correlations between all the indicators of classroom democracy and learning outcomes in the context of Francophone African countries. However, only the association between child discipline and the learning outcomes is significant, the correlations of the other indicators of classroom democracy with educational achievements are insignificant. The positive association between indicator of group work and educational outcomes means that when pupils are given the opportunity to work in small groups, they are more likely to have higher test scores. The positive association between indicator of group work and learning outcomes corroborates findings from some earlier studies such as Feinberg \& Toress (2001) and Lipton \& Oakes (2003) who found that when pupils participate actively in class and work as teams, their educational achievements are much higher. Unfortunately, our positive correlation is insignificant. In the survey about $63.2 \%$ of the teachers reported not organising pupils to work in groups. Furthermore, about $67.3 \%$ of the teachers lacked the techniques to do so (see Table S1 in the Appendix). Children in the African family setting share responsibilities in carrying out household chores such as cooking, taking 
care of babies, fetching firewood and water, and running errands for the elderly. Thus at an early age African children are exposed to a 'team-spirit way' of living which unfortunately is disrupted in the classroom when the teacher fails to organise them to work in groups. Children will learn better in a classroom atmosphere, where children work in smaller groups, feel safe to express their feelings and open discussions are encouraged. Therefore, there is need in African countries to move away from the traditional mode of teaching and learning where children listen and teachers speak and dictate notes.

The estimation results indicate positive but insignificant correlations between indicator of children's rights and learning outcomes. As a follow up of the 1989 UN Convention on children's right, a special session was held on 22 May 2002 on children during which countries committed to invest in children and adopt policies in the best interest of the child. Francophone African countries have several developmental challenges such as low incomes, inadequate access to portable water and sanitation, food insecurity and hunger, and widespread disease that threaten children's livelihoods (Watkins, 2016). Given these challenges it is no surprise that $57.5 \%$ of the pupils in the survey reported feeling hungry in class, more than $77-83 \%$ reported having one health impairment or another and $73.6 \%$ did not attain nursery school. A further $36 \%$ of the children have never slept under a mosquito net (see Table S2). These are basic rights of the child. The inability of the children's families to respect these rights may account for the insignificant nature of the results. It would be a miracle to expect children to achieve significantly when such basic rights are not respected. In tandem with African culture children in poorer families may be required to carry out petty commercial activities, or join their parents in farming so as to help the family survive. In western culture this may be considered child labour or child abuse, but in the African context this is not only a livelihood survival strategy but is often considered a normal activity in line with the household chores distribution plan of the family. Thus, I may further argue that differences of this nature in the conceptualisation of children's rights may also account for the insignificance of the estimation result.

The indicator of child discipline associates positively and significantly with learning outcomes. This result is in line with expectations and agrees with Bodovski, Nahum-Shani, \& Walsh (2013), which showed that higher math scores were registered among US students in a disciplinary school environment. Further, Ning, Van-Damme, Yang, \& Gielen, (2013) also obtain a positive and significant correlation between child discipline and reading achievements. Furthermore, Pasternak (2013) and Zhao \& Kuo (2015) have reported positive and significant relationships between children's self-discipline and non-cognitive achievements. Some unique features of the African traditional society may account for the significance of the child discipline indicator in this study. The extended family system is a powerful tool in parenting and helps to develop a sense of social responsibility, cooperation, and respect for elders in the child's early years (Nsamenang, 2008). Another feature in the African traditional society aspect is the telling of folktales. This is another form of parenting which inculcates good morals and discipline in children (Degbey, 2012). Given these indigenous cultural values, the African child at an early age is more likely to be disciplined and by extension more likely to respect classroom rules and regulations.

The indicator of cultural identity indicates a positive but insignificant association with learning outcomes. This finding slightly differs from results of earlier studies, like Okonji (1971); Bodrova \& Leong (2007); Marfo \& Biersteker (2011) which find that cultural values have positive and significant effects on children's academic performance. A close look at the items in the 2014 PASEC survey from which the indicator of cultural identity is constructed may provide some explanation for the insignificance of estimation result. Only about $18.9 \%$ of the teachers expressed themselves in the native language of the pupils where the school is located; $70.7 \%$ of the teachers did not allow pupils to speak, and sing in class in their native language and worst still only $8.6 \%$ of the pupils speak exclusively the mother tongue at home (see Table S4). These attitudes are not of a nature to facilitate learning and ameliorate academic achievements in the African context. Mucherah \& Mbogori (2019) argue that African children will learn better if the native language and French/English are used simultaneously as languages of instructions in school. This will facilitate the use of local examples to introduce the alphabet and counting of objects. Unfortunately, Francophone African scholars are still caught in the empty pride of using examples from Paris, France, during lessons in class. African children may not quickly figure out such examples in their local context. Some parents are also still entangled in the web of colonisation, and feel more westernised if their children speak only French/English. African 
educationists have to encourage a shift away from these colonial mental enslavement and practices.

\section{Conclusion}

\section{Conclusion and Policy Implications}

This study attempts to shed light on the effects of classroom democratic practices on cognitive (math and reading) and non-cognitive (self-esteem and sociability) learning outcomes using cross-sectional data from Francophone African countries. To capture the inter-relationships inherent in the education production process, a simultaneous equation modeling approach is proposed. In order to estimate the model parameters, an error component- two stage least squares-instrumental variable method is used to properly account for the multilevel nature of the data structure. The results confirm the endogenous nature of the learning outcome variables; specifically, they indicate positive and significant correlations among the learning outcomes. As regards classroom democratic practices, the results indicate positive and insignificant associations with the dimensions of group work, children's rights, and cultural identity. Only the indicator of child discipline has positive and significant effect on learning outcome skills in this study. The exogenous or control variables included in the model have significant expected signs, notably family size, socio-economic status, teacher experience, community involvement, and classroom pedagogic resources.

\section{Policy Implications}

From the findings of this study, it stands out that teachers and parents are some of the most important stakeholders in the process of having children internalize democracy in the classroom. In this regard, the following policy recommendations are made:

Teachers should initiate and encourage children to work in small groups in the classroom. Teachers should develop the habit to invite pupils to always see themselves as capable and valuable. This action will bring out the positive traits and potentials that the children have and help to build their self-esteem which is a strong internal motivation to educational achievement. Education stakeholders should take measures to preserve and promote indigenous cultural values because they tend to facilitate learning achievements. Education policy makers should devote more resources to revise the curriculum of professional colleges in order to train teachers to: i) develop skills of assigning and supervision of pupils in team work; ii) be culturally responsive in their teaching practices and accommodate pupils who speak their native language, or display their cultural identity in class. Therefore, the teacher would be acting like a classroom democratic model. Educationists should develop parenting programmes to sensitise parents to speak their native languages with children at home, and how to better prepare children for schooling as regards nutrition, health, and other nurturing issues. The findings also showed that there are variations in achievements within schools and between schools. The implication of this result is that educationists must design multiple teaching strategies. A blind spot in the education system is an attempt to treat all children the same. This certainly is for reasons of equity and fairness, but in reality, children are all different given that they come from diverse backgrounds. 


\section{References}

Anderson, L.W., Krathwohl, D.R., Airasian, P.W., Cruikshank, K.A., Mayer, R.E., Pintrich, P.R., Raths, J., \& Wittrock, M.C. (2001). A taxonomy for learning, teaching, and assessing: A revision of Bloom's Taxonomy of Educational Objectives. New York: Pearson, Allyn and Bacon.

Baltagi, B. H. (2008). Econometric analysis of panel data. (4th Ed.). New York: Wiley.

Baltagi, B. H. (2011). Simultaneous equations model. (5th Ed.). Berlin, Heidelberg: Springer.

Baltagi, B. H., \& Chang, Y. J. (2000). Simultaneous equations with incomplete panels. Econometric Theory, 16(2), 269-279.

Bandura, A. (1977). Social learning Theory. New York: General Learning Press.

Barron, B., \& Darling-Hammond, L. (2008). Teaching for meaningful learning: A review of research on inquiry-based and cooperative learning. Stanford, CA: Stanford University.

Baumeister, R. F., Campbell, J. D., Krueger, J. I., \& Vohs, K. D. (2003). Does high self-esteem cause better performance, interpersonal success, happiness, or healthier lifestyles? Psychological Science in the Public Interest, 4(1), 1-44.

Bodovski, K., Nahum-Shani, I. \& Walsh, R. (2013). School disciplinary climate and students' early mathematics learning: Another search for contextual effects? American Journal of Education, 119(2), 209-234.

Bodrova, E., \& Leong, D.J. (2007). Tools of the mind: The Vygotskian approach to early childhood education. (2nd Ed). Upper Saddle River, NJ: Merrill/Prentice Hall.

Borghans, L., Duckworth, A. L., Heckman, J. J., \& Ter Weel, B. (2008). The economics and psychology of personality traits. Journal of Human Resources, 43(4), 972-1059.

Chamorro-Premuzic, T., \& Furnham, A. (2003). Personality predicts academic performance: Evidence from two longitudinal university samples. Journal of Research in Personality, 37(4), 319-338.

Deci, E. L., Vallerand, R. J., Pelletier, L. G., \& Ryan, R. M. (1991). Motivation and education: The self-determination perspective. Educational Psychologist, 26, 325-346.

Degbey, J. L. (2012). Africa family structure. Retrieved from http://www.jicef.or.jp/wahec/ful217.htm
Emler, N. (2001). Self esteem: The costs and causes of low self worth. York Publishing Services.

Fearnley-Sander, M., Moss, J., \& Harbon, L. (2001). The civic school: Australian-Indonesian professional collaboration to model and audit the development of democratic primary classrooms and teacher language using the Index for Inclusion. Paper presented at the Australian Association Research in Education (AARE) Conference, Sydney.

Feinberg, W., \& Torres, C. A. (2001). Democracy and education: John Dewey and Paulo Freire. Education and Society, 59-70.

Fielding, A. (2010). Module 8: Multilevel modelling in practice: Research questions, data preparation and analysis. LEMMA VLE, University of Bristol, Centre for Multilevel Modelling.

Glewwe, P. (2002). Schools and skills in developing countries: Education policies and socioeconomic outcomes. Journal of Economic Literature, 40(2), 436-482.

Glewwe, P. \& Jacoby, H. (1994). Student achievement and schooling choice in low-income countries: Evidence from Ghana. Journal of Human Resources, 843-864.

Glewwe, P., \& Kremer, M. (2006). Schools, teachers, and education outcomes in developing countries. Handbook of the Economics of Education, 2, 945-1017.

Greene, W. H. (2011). Econometric analysis. (7th Ed.) Upper Saddle River, NJ: Prentice Hall.

Harter, S. (2012). The construction of the self. (2nd ed.). New York: Wiley.

Hsiao, C. (2003). Analysis of Panel Data (2 bs.). İngiltere: Cambridge University.

Levin, J., \& Nolan, J. F. (1991). Principles of classroom management: A hierarchical approach. Prentice Hall.

Lipton, M., \& Oakes, J. (2003). Teaching to change the world (2nd ed.). Boston: McGraw Hill.

Maftoon, P., \& Shakouri, N. (2012). The concept of power in teacher talk: A critical discourse analysis. World Applied Sciences Journal, 19(8), 1208-1215. doi: 10.5829/idosi.wasj.2012.19.08.1894

Marfo, K., \& Biersteker, L. (2011). Exploring culture, play and early childhood education practice in African contexts. In S. Rogers (Ed.), Rethinking play and pedagogy in early childhood education (pp. 73-85). New York, NY: Routledge. 
Marfo, K., Pence, A. R., LeVine, R. A., \& LeVine, S. (2011). Strengthening Africa's contributions to child development research: Introduction. Child Development Perspectives, 5(2), 104-111.

Mothata, W. \& Squelch, J. (1997). Eight keys to effective school management in South Africa. Halfway House: Southern Book Publishers.

Mucherah, W. \& Mbogori, T. (2019). Examining child development from an African cultural context. Global Journal of Transformative Education, 1(1), 11-17. doi: 10.14434/gjte.v1i1.26140

Nagaraju, C., Madhavaiah, G., \& Peter, S. (2013). Teacher-centred learning and student-centred learning in English classroom: The teaching methods realizing the dreams of language learners. International Journal of Scientific Research and Reviews, 2(3), 125-131.

Ning, B., Van -Damme, J., Yang , X., \& Gielen, S. (2013). September). Does classroom disciplinary climate in a school matter everywhere? A cross-country comparative study. Paper presented at The 2013 Annual Meeting of the European Conference on Educational Research, Istanbul, Turkey.

Njong, A. M., \& Ningaye, P. (2008). Characterizing weights in the measurement of multidimensional poverty: An application of data-driven approaches to Cameroonian data. OPHI Working Paper No. 21.

Noftle, E. E., \& Robins, R. W. (2007). Personality predictors of academic outcomes: Big five correlates of GPA and SAT scores. Journal of Personality and Social Psychology, 93(1), 116.

Nsamenang, A.B. (2008). Constructing cultural identity in families, In: Brooker, L. and Woodhead, M. (Eds.). Social inclusion and respect for diversity: Developing positive identities. Milton Keynes, Buckinghamshire, UK: The Open University.

Okonji, M. O. (1971). The effects of familiarity on classification. Journal of Cross-Cultural Psychology, 2, 39-49.

Olsen, J. M., Breckler, S. J., \& Wiggens, E. C. (2008). Social psychology alive. Toronto: Thomson Nelson.
PASEC (1998). L'enseignement primaire au Cameroun: investigations et diagnostics pour l'amélioration de la qualité du système éducatif. PASEC, CONFEMEN, Dakar.

PASEC (2017). Manuel d'exploitation des données: Évaluation internationale PASEC2014. PASEC, CONFEMEN, Dakar.

Papadopoulos, K., Metsiou, K., \& Agaliotis, I. (2011). Adaptive behaivor of children and adolescents with visual impairments. Research in Developmental Disabilities, 32, 1086-1096.

Pasternak, R. (2013). Discipline, learning skills and academic achievement. Journal of Arts and Education, 1(1), 1-11.

Saigal, S., Lambert, M., Russ, C., \& Hoult, L. (2002). Self-esteem of adolescents who were born prematurely. Pediatrics, 109, 429-433.

Serpell, R., \& Marfo, K. (2014). Some growth points in African child development research. in R. Serpell \& K. Marfo (Eds.), Child development in Africa: Views from inside. New Directions for Child and Adolescent Development, 146, 97-112.

UN General Assembly. (1989). Convention on the Rights of the Child. United Nations, Treaty Series, 1577(3).

Wamalwa, F. M., \& Burns, J. (2018). Teacher Human Capital, Teacher Effort and Student Achievements in Kenya (No. 722).

Watkins, K. (2016). The State of the World's Children 2016: A Fair Chance for Every Child. New York: UNICEF.

Woolridge, J. M. (2009). Introductory cconometrics: A modern approach. (4. Ed). South-Western, Michigan State University, 378, 57.

Zhao, R., \& Kuo, Y. L. (2015). The role of self-discipline in predicting achievement for 10th graders. International Journal of Intelligent Technologies and Applied Statistics, 8(1), 61-70. doi: 10.6148/IJITAS.2015.0801.05

\section{Author}

Aloysius Mom Njong (mom_aloys@yahoo.fr) is a Professor of Development Economics at the University of Bamenda, Cameroon. 
Table S1. Weighted frequency distribution of teachers' responses to group work items

\begin{tabular}{lcc}
\hline & \multicolumn{2}{c}{ Responses (\%) } \\
\cline { 2 - 3 } Items & Yes & No \\
\hline Teacher organises pupils to work in small groups in class & 36.84 & 63.16 \\
Teacher organises pupils to work in groups to clean classroom & 38.20 & 61.80 \\
& & \\
and toilets & 32.70 & 67.30 \\
Teacher has the techniques to make pupils work in groups & 20.34 & 79.66 \\
Teacher gives assignment to class head to lead sub-groups & 73.92 & 26.08 \\
Pupils perform better when they discuss among themselves & 43.77 & 56.23 \\
The classroom is not appropriate to organise pupils in groups & $\mathbf{0 . 7 4 5}$ & \\
Guttman's split Lambda coefficient & & \\
\hline
\end{tabular}

Table S2. Weighted frequency distribution of pupils' responses to children's rights items

\begin{tabular}{lcc}
\hline & \multicolumn{2}{c}{ Responses (\%) } \\
\cline { 2 - 3 } Items & Yes & No \\
\hline Did you attain nursery school? & 26.39 & 73.61 \\
Do you sleep under mosquito net? & 64.10 & 35.90 \\
Do you have hearing difficulty? & 17.65 & 82.35 \\
Do you have sight problems? & 23.00 & 77.00 \\
Are you afraid, or feel unsecured in class? & 22.5 & 77.5 \\
Do you often feel tired in class? & 19.15 & 80.85 \\
Do you often feel hungry when in class? & 57.47 & 42.53 \\
Guttman's split Lambda coefficient & $\mathbf{0 . 7 8 6}$ & \\
\hline
\end{tabular}

Table S3. Weighted frequency|distribution of teachers' responses to child discipline items

\begin{tabular}{lcccc}
\hline \multirow{2}{*}{ Items } & \multicolumn{2}{c}{ Responses (\%) } & & \\
\cline { 2 - 5 } & Always & Often & $\begin{array}{c}\text { Occasion } \\
\text {-ally }\end{array}$ & Never \\
\hline $\begin{array}{l}\text { Teacher punishes/shouts at } \\
\text { children in class }\end{array}$ & 8.28 & 30.05 & 56.51 & 5.16 \\
$\begin{array}{l}\text { Teacher punishes pupils to write } \\
\text { exercises }\end{array}$ & 3.93 & 28.53 & 42.40 & 25.15 \\
$\begin{array}{l}\text { Teacher punishes pupils to cut } \\
\text { grass, sweep the yard }\end{array}$ & 11.58 & 38.00 & 32.85 & 17.57 \\
$\begin{array}{l}\text { Teacher sends the recalcitrant } \\
\text { pupil to the head teacher }\end{array}$ & 3.44 & 22.17 & 49.48 & 24.92 \\
$\begin{array}{l}\text { Teacher keeps the pupil standing at } \\
\text { corner in classroom }\end{array}$ & 0.95 & 9.96 & 22.13 & 66.96 \\
$\begin{array}{l}\text { Teacher administers physical } \\
\text { punishment (beats. ) }\end{array}$ & 0.37 & 5.14 & 31.05 & 63.44 \\
$\begin{array}{l}\text { Teacher punishes or beats when } \\
\text { pupils have low test scores }\end{array}$ & 0.49 & 4.88 & 32.72 & 61.91 \\
Cronbach's alpha & 0.701 & & & \\
\hline
\end{tabular}


Table S4. Frequency distribution of teacher/pupils' responses to cultural identity items

\begin{tabular}{|c|c|c|c|c|}
\hline \multirow[b]{2}{*}{ Items } & \multicolumn{4}{|c|}{ Responses (\%) } \\
\hline & $\begin{array}{l}\text { Alway } \\
s\end{array}$ & Often & $\begin{array}{l}\text { Occasional } \\
\text { ly }\end{array}$ & $\begin{array}{l}\text { Neve } \\
\mathbf{r}\end{array}$ \\
\hline $\begin{array}{l}\text { Native language is spoken at the } \\
\text { home of the child }\end{array}$ & 8.57 & 0.00 & 69.03 & 22.41 \\
\hline $\begin{array}{l}\text { Teacher uses native language spoken } \\
\text { by the majority of the children }\end{array}$ & 3.45 & 15.51 & 62.63 & 18.41 \\
\hline \multirow{2}{*}{$\begin{array}{l}\text { Teacher allows children sing songs, } \\
\text { express themselves in native } \\
\text { language in class }\end{array}$} & 6.75 & 10.14 & 12.39 & 70.73 \\
\hline & Yes & & No & \\
\hline $\begin{array}{l}\text { There are text books in native } \\
\text { language of the majority of the } \\
\text { children }\end{array}$ & 22.30 & & 77.70 & \\
\hline $\begin{array}{l}\text { There are text books in native } \\
\text { language showing } \\
\text { math/classification of figures }\end{array}$ & 15.50 & & 84.50 & \\
\hline Cronbach's alpha & 0.595 & & & \\
\hline
\end{tabular}

Table S5. Weighted frequency distribution of pupils' responses to self-esteem items

\begin{tabular}{lcccc}
\hline \multirow{2}{*}{ Items } & \multicolumn{2}{c}{ Responses (\%) } & & \\
\cline { 2 - 5 } & $\begin{array}{c}\text { Strongly } \\
\text { agree }\end{array}$ & Agree & Disagree & $\begin{array}{c}\text { Strongly } \\
\text { disagree }\end{array}$ \\
\hline $\begin{array}{l}\text { I perform well in class } \\
\text { I have good scores because I work hard }\end{array}$ & 28.16 & 52.85 & 11.60 & 5.27 \\
$\begin{array}{l}\text { I have good scores because the lessons } \\
\text { in class are very easy }\end{array}$ & 26.52 & 47.46 & 18.83 & 7.78 \\
$\begin{array}{l}\text { I have low scores because I don't put in } \\
\text { much effort }\end{array}$ & 13.84 & 28.47 & 35.39 & 22.31 \\
$\begin{array}{l}\text { I have low scores because the lessons } \\
\text { in class are very difficult }\end{array}$ & 12.63 & 29.09 & 37.11 & 21.18 \\
$\begin{array}{l}\text { I have low scores because I am not } \\
\text { intelligent enough }\end{array}$ & 10.66 & 25.53 & 40.94 & 22.87 \\
$\begin{array}{l}\text { I have low scores because the teacher } \\
\text { often says that I am lazy and foolish } \\
\text { Cronbach's alpha }\end{array}$ & 8.25 & 16.43 & 45.14 & 30.18 \\
\hline
\end{tabular}

Table S6. Weighted frequency distribution of pupils' responses to sociability items

\begin{tabular}{|c|c|c|c|c|}
\hline \multirow[b]{2}{*}{ Items } & \multicolumn{4}{|c|}{ Responses (\%) } \\
\hline & $\begin{array}{l}\text { Strongly } \\
\text { agree }\end{array}$ & Agree & Disagree & $\begin{array}{l}\text { Strongly } \\
\text { disagree }\end{array}$ \\
\hline I have many friends in school & 34.92 & 49.41 & 10.52 & 5.16 \\
\hline $\begin{array}{l}\text { The other children do not play } \\
\text { with me }\end{array}$ & 11.94 & 25.39 & 38.22 & 24.45 \\
\hline $\begin{array}{l}\text { I am happy being in school, } \\
\text { because other kids like me }\end{array}$ & 38.46 & 48.34 & 8.43 & 4.77 \\
\hline $\begin{array}{l}\text { Other children want me to be } \\
\text { their friend }\end{array}$ & 10.26 & 21.05 & 42.07 & 26.62 \\
\hline Cronbach's alpha & 0.516 & & & \\
\hline
\end{tabular}

